\title{
HUBUNGAN FREKUENSI KONSUMSI GLUTEN, KASEIN, DAN ASUPAN SERAT DENGAN POLA DEFEKASI ANAK AUTIS.
}

\author{
Alsha Listyobudi Hertanti, Yekti Wirawanni*) \\ Program Studi Ilmu Gizi Fakultas Kedokteran Universitas Diponegoro \\ J1.Dr.Sutomo No.18, Semarang, Telp (024) 8453708, Email : gizifk@ undip.ac.id
}

\begin{abstract}
Background : Gastrointestinal symptoms and abnormalities in stool consistency are recently increasing reported by parents of children with autism spectrum disorders. Foods that contain gluten and casein activated mucosal immune response and caused the presence of abnormal gut microbiota. The purpose of this study was to determine the relationship between frequency consumption of gluten, casein, and fiber intake with defecation of autism children.

Methods : Observational study with cross-sectional design in SLB Negeri Tarakan and SLB Kasih Bahagia. Sample were 30 subjects and selected by consecutive sampling.

Results : Autism was higher in males (83.3\%) than female. Most of frequency consumption gluten was in sometimes category (33,3\%) and casein was in never category (33,3\%). The average of fiber intake was 19,9 g/day and most of subjects have a low category fiber intake (63,3\%). This study showed that most of subjects have an abnormal frequency defecation (63,3\%) and hard stool (73,3\%). Based on correlation test, there was no correlation between frequency consumption of gluten and casein with frequency defecation and stool consistency $(p>0.05)$. Fiber intake is correlated with frequency defecation $(r=0.468, p=0.009)$. There was significant correlation between fiber intake with stool consistency $(r=0.837, p=0.000)$.

Conclusion: There was no correlation between frequency consumption of gluten and casein with frequency defecation and stool consistency. Fiber intake is correlated with frequency defecation and very significant with stool consistency. Keywords : frequency consumption; gluten; casein; fiber; autism; defecation
\end{abstract}

\begin{abstract}
ABSTRAK
Latar Belakang : Gangguan pencernaan dan abnormal konsistensi feses dilaporkan semakin meningkat oleh para orang tua dari anak autis. Makanan yang mengandung gluten dan kasein dapat memicu pengaktifan respon sistem imun mukosa usus dan menyebabkan timbulnya abnormal mikroflora usus. Penelitian ini bertujuan untuk mengetahui hubungan antara frekuensi konsumsi gluten, kasein, dan asupan serat, dengan pola defekasi pada anak autis.

Metode : Penelitian observasional dengan design cross-sectional yang dilakukan di SLB Negeri dan SLB Kasih Bahagia Tarakan. Jumlah sampel sebanyak 30 dan dipilih dengan metode consecutive sampling.

Hasil : Penderita autis lebih banyak ditemukan pada laki-laki (83,3\%) dibandingkan perempuan. Sebagian besar frekuensi konsumsi gluten termasuk dalam kategori kadang (33,3\%), dan kasein dalam kategori tidak pernah (33,3\%). Rata-rata asupan serat 19,9 gram/hari dan sebagian besar asupan serat subjek kurang (63,3\%). Penelitian ini menunjukkan bahwa sebagian besar subjek (63,3\%) memiliki frekuensi defekasi yang tidak normal dan konsistensi feses yang keras (73,3\%). Hasil uji korelasi menunjukkan tidak ada hubungan antara frekuensi konsumsi gluten dan kasein dengan frekuensi defekasi dan konsistensi feses ( $p>0.05)$. Ada hubungan antara asupan serat dengan frekuensi defekasi ( $r=0.468, p=0.009)$. Terdapat hubungan yang signifikan antara asupan serat dengan konsistensi feses $(r=0.837, p=0.000)$.

Simpulan : Tidak terdapat hubungan antara frekuensi konsumsi gluten dan kasein dengan frekuensi defekasi dan konsistensi feses. Terdapat hubungan antara asupan serat dengan frekuensi defekasi dan sangat signifikan dengan konsistensi feses.
\end{abstract}

Kata kunci : frekuensi konsumsi; gluten; kasein; serat; autis; defekasi

\section{PENDAHULUAN}

Autisme

merupakan

gangguan perkembangan fungsi otak yang berpengaruh pada interaksi sosial dan keahlian berkomunikasi. Selain itu, kesulitan dalam melakukan komunikasi verbal dan nonverbal, interaksi sosial, serta beberapa aktivitas juga nampak pada anak autis. ${ }^{1}$ Saat ini kasus autisme mengalami kenaikan yang signifikan. Kenaikan ini terjadi tidak hanya di negara maju, melainkan juga terjadi di negara berkembang seperti Indonesia. The Center for Disease Control merilis data prevalensi autisme di Amerika Serikat mencapai 1 kasus per 68 anak pada tahun 2013. Angka ini menunjukkan peningkatan dibandingkan tahun 2012 yaitu 1:88 anak, dan 1:110 di tahun $2009 .^{2}$ Indonesia sampai saat ini belum memiliki angka pasti jumlah kasus autisme karena belum adanya survei skala nasional. ${ }^{3}$

Adanya karakteristik gangguan perilaku yang nampak pada anak autis sering dikaitkan dengan teori kelebihan opioid yang sampai saat ini masih terus diteliti lebih lanjut. Teori kelebihan

\footnotetext{
${ }^{*}$ Penulis Penanggungjawab
} 
opioid ini menyebutkan bahwa kondisi permeabilitas usus yang tinggi mengakibatkan peptide opioid tidak tercerna dengan sempurna lalu beredar ke otak. Aktifitas opioid yang berlebihan di otak kemudian mempengaruhi persepsi, kognisi, emosi, dan persepsi pada anak autis. ${ }^{4}$ Tidak hanya gangguan perilaku, anak autis juga cenderung mengalami gangguan pencernaan dibandingkan dengan anak normal. ${ }^{5}$

Dalam penelitian kasus-kontrol terhadap kelompok autis dan kontrol (non autis), kejadian gangguan pencernaan pada kelompok autis lebih dominan dibandingkan kelompok kontrol. yaitu berupa konstipasi $(33,9 \%$ vs $17,6 \%)$, diare $(50,3 \%$ vs $41,6 \%)$, dan nyeri abdominal $(25,3 \%$ s $16,9 \%){ }^{6}$

Asupan kasein menjadi salah satu pemicu konstipasi pada anak autis berkaitan dengan casomorphin peptide dalam protein susu yang memiliki efek fisiologis seperti opioid sehingga bisa memperpanjang waktu transit feses. ${ }^{7-9}$

Konsumsi gluten membuat peptide yang tidak tercerna juga masuk ke dalam ileum dan usus besar, kemudian menjadi makanan flora usus abnormal dan menimbulkan gangguan pencernaan. ${ }^{10}$

Penelitian observasional lain juga menyebutkan bahwa anak autis yang tidak mengkonsumsi gluten dan kasein cenderung tidak mengalami gangguan pencernaan. ${ }^{11}$

Kesehatan pencernaan pada anak secara umum dapat dilihat melalui pola defekasi. Gangguan pencernaan berkaitan dengan pola defekasi berupa abnormal frekuensi defekasi dan konsistensi feses pada anak autis memerlukan pemantauan yang lebih agar tidak memperparah gangguan perilaku dan ketidakstabilan emosi. Oleh karena itu peneliti tertarik untuk melakukan penelitian dengan tujuan untuk mengetahui bagaimana frekuensi konsumsi gluten, kasein dan asupa serat berkaitan dengan pola defekasi pada anak autis.

\section{METODA}

Penelitian ini dilakukan di SLB Kasih Bahagia dan SLB Negeri kota Tarakan pada bulan Mei-Juni 2014. Jenis penelitian yang digunakan adalah observasional dengan desain cross sectional. Responden dalam penelitian ini ibu maupun orang tua wali dari anak autis yang menjadi subjek penelitian.

Metode pengambilan sampel yang digunakan yaitu consecutive sampling sesuai dengan kriteria inklusi dan eksklusi. ${ }^{12}$ Kriteria inklusi meliputi responden yang bersedia mengikuti jalannya penelitian dan menandatangani informed consent, usia subjek 3-13 tahun, dan subjek tidak memiliki gangguan fisik atau mental lainnya. Untuk kriteria eksklusi diantaranya subjek pindah sekolah dan responden mengundurkan diri saat penelitian berlangsung.

Berdasarkan teknik sampling diatas didapatkan 30 orang yang bersedia menjadi responden. Tidak terdapat responden yang drop out. Pengumpulan data dilakukan dengan metode wawancara. Selain itu juha dilakukan diskusi kelompok dengan 30 responden di ruangan yang telah disediakan oleh pihak sekolah. Diskusi ini juga bertujuan untuk membantu responden mengidentifikasi sumber gluten dan kasein.

Data yang dikumpulkan yaitu identitas subjek meliputi berat badan, tinggi badan. Alat yang digunakan yaitu microtoise dan timbangan injak. Untuk menghitung status gizi digunakan bantuan program WHO Anthro plus.

Kategori status gizi berdasarkan indeks massa tubuh menurut umur yaitu yaitu obesitas jika $>+2 \mathrm{SD}$, overweight jika $>+1 \mathrm{SD}$ sampai $+2 \mathrm{SD}$, normal jika $\geq-2$ SD sampai $\leq+1 \mathrm{SD}$, kurus jika $\geq-3 \mathrm{SD}$ sampai <2SD, sangat kurus jika <-3SD. ${ }^{13}$ Metode pengukuran konsumsi makanan menggunakan dietary history, dengan komponen recall 24 jam dan checklist bahan makanan gluten dan kasein. ${ }^{14}$ Pola konsumsi gluten dan kasein dikategorikan menjadi sering sekali : > 6x per minggu, sering : $3-6 x$ per minggu, kadang : 1-2x per minggu, jarang : $<1$ per minggu, tidak pernah : 0 per minggu/tidak mengkonsumsi. ${ }^{11,15}$ Tingkat asupan serat dikategorikan menjadi baik : 100-120\%, sedang : 80-99\%, kurang : $70-80 \%$, defisit : $<70 \%$ diperoleh melalui perbandingan dengan AKG sesuai dengan umur subjek. ${ }^{16,17}$ Data pola defekasi meliputi frekuensi defekasi dan konsistensi feses diukur dengan menggunakan buku harian pola defekasi terstandar dikombinasikan dengan Bristol Scale. Frekuensi defekasi dikategorikan menjadi normal : $>3 x$ per minggu dan tidak normal : $<3 x$ per minggu. Konsistensi feses dikategorikan menjadi keras : tipe feses 1-3, dan lunak : tipe feses 4-5. ${ }^{18}$

Analisis data untuk mengetahui hubungan frekuensi konsumsi gluten, kasein, dan asupan serat dengan pola defekasi menggunakan uji korelasi Spearman dengan didahului uji Shapiro-Wilk.

\section{HASIL DAN PEMBAHASAN Karakteristik Subjek}

Subjek dalam penelitian ini berjumlah 30 . Karakteristik subjek berdasarkan umur yaitu responden termuda berusia 3 tahun, sedangkan umur tertinggi 12 tahun. Sebanyak 15 anak (50\%) berada di tingkat TK dan PAUD, sedangkan sebanyak 15 anak (50\%) di tingkat SD. 
Karakteristik subjek berdasarkan jenis kelamin adalah sebanyak 25 subjek laki-laki $(83,3 \%)$, dan perempuan sebanyak $5(16,7 \%)$. Hasil penelitian ini menunjukkan bahwa penyandang autis lebih dominan pada jenis kelamin laki-laki serupa dengan penelitian Lonnie. ${ }^{26}$

Tabel 1. Status gizi subjek

\begin{tabular}{|c|c|c|}
\hline Status Gizi & $\mathrm{N}$ & $\%$ \\
\hline Sangat kurus & 2 & 6.7 \\
\hline Kurus & 3 & 10 \\
\hline Normal & 14 & 46.7 \\
\hline Overweight & 7 & 23.3 \\
\hline Obesitas & 4 & 13.3 \\
\hline Total & 30 & 100 \\
\hline
\end{tabular}

Karakteristik subjek berdasarkan status gizi adalah sebanyak 4 subjek obesitas $(13,3 \%)$, overweight sebanyak 7 (23,3\%), normal 14 $(46,7 \%)$, kurus $3(10 \%)$, dan sangat kurus sebanyak 2 subjek $(6,7 \%)$. 2 subjek dengan status gizi sangat kurus mengalami permasalahan pola makan dikarenakan tingkat selektifitas makanan dan sensori bau yang tinggi. Subjek cenderung memilihmilih makanan berdasarkan kesukaanya dan tantrum (suka mengamuk).

\section{Karakteristik responden}

Karakteristik keluarga terutama pekerjaan ibu mempengaruhi status gizi anak. Ibu yang bekerja semakin sedikit memiliki waktu dan perhatian terhadap asupan anak. Pekerjaan responden pada penelitian ini sangat bervariasi, sebagian besar ayah subjek bekerja sebagai wiraswasta (50\%), sisanya pns (13,3\%), karyawan swasta $(30 \%)$, tentara $(3,3 \%)$, dan buruh $(3,3 \%)$. Pendidikan ayah dominan di tingkat SMA $(56,7 \%)$. Sebagian besar ibu dari subjek tidak bekerja (70\%), sisanya wiraswasta $(16,7 \%)$, karyawan swasta dan pns sebanyak $6,7 \%$. Mayoritas pendidikan ibu di tingkat SMA (60\%).

Frekuensi konsumsi gluten, kasein, dan serat subjek

Pola makan adalah susunan jenis dan jumlah makanan yang dikonsumsi seseorang atau kelompok orang pada waktu tertentu. Pola konsumsi terdiri dari frekuensi makan dan jenis makanan. Frekuensi makan merupakan jumlah makan dalam sehari-hari baik kualitatif dan kuantitatif. ${ }^{28}$

Makanan yang mengandung gluten yaitu semua makanan yang dibuat dari tepung terigu, havermouth, dan oat seperti mie, roti, kue kering, cake, biskuit, pizza, makaroni, spaghetti, dan tepung bumbu. Sumber kasein susu dan hasil olahannya seperti es krim, keju, mentega, yoghurt, dan makanan yang menggunakan campuran susu. ${ }^{32-}$ 33

Tabel 2. Distribusi frekuensi konsumsi glutein, kasein dan asupan serat

\begin{tabular}{lllcc}
\hline No & & \multicolumn{2}{c}{ Frekuensi } \\
\cline { 4 - 5 } & & & $\mathrm{n}$ & $\%$ \\
\cline { 3 - 5 } & & & \multicolumn{2}{c}{} \\
\hline 1. & Frekuensi & Sering sekali & 7 & 6,7 \\
& konsumsi & Sering & 10 & 33,3 \\
& gluten & Kadang & 9 & 30 \\
& & Jarang & 2 & 6,7 \\
& & Tidak pernah & & \\
\hline 2. & Frekuensi & Sering sekali & 1 & 3,3 \\
& konsumsi & Sering & 4 & 13,3 \\
& kasein & Kadang & 6 & 20 \\
& & Jarang & 9 & 30 \\
& & Tidak pernah & 10 & 33,3 \\
\hline 3. & Asupan serat & Baik & 2 & 6,7 \\
& & Sedang & 8 & 26,7 \\
& & Kurang & 19 & 63,3 \\
& & Defisit & 1 & 3,3 \\
\hline
\end{tabular}

Pada penelitian ini sebagian besar subjek masih mengkonsumsi gluten dan hanya 2 subjek
$(6,7 \%)$ yang benar-benar tidak mengkonsumsi gluten. Sumber gluten yang paling sering 
dikonsumsi subjek yaitu mie dan berbagai macam wafer dan biskuit. Bakso, nugget, dan sosis dikonsumsi dengan frekuensi 1-2x per minggu. Pisang goreng serig dikonsumsi $3-6 x$ per minggu oleh subjek. Sumber kasein yang paling sering dikonsumsi subjek penelitian ini yaitu susu sapi.

Serat makanan adalah komponen bahan pangan yang tidak dapat dicerna oleh enzim-enzim dalam saluran pencernaan. Pada penelitian sebagian besar subjek memiliki asupan serat yang kurang $(63,3 \%)$.

\section{Pola Defekasi}

Pola defekasi dianggap menjadi indikator kesehatan saluran pencernaan. Pola defekasi pada anak autis dipengaruhi oleh faktor pola makan, toilet training, dan Obat-obatan. ${ }^{23}$ Konstipasi dan diare tergolong dalam gangguan pada pola defekasi. Gangguan pola defekasi pada anak autis dapat menimbulkan dampak negatif diantaranya menurunkan kemampuan berkonsentrasi, memperparah ketidakstabilan emosi, mengganggu proses detoksifikasi dan metabolisme zat gizi di saluran pencernaan. Hal ini juga didukung dengan ketidakmampuan mereka mengkomunikasikan keluhan yang mereka rasakan. ${ }^{24}$

Tabel 3. Pola defekasi

\begin{tabular}{lcc}
\hline Frekuensi defekasi & n & \% \\
\hline Normal & 11 & 36,7 \\
Tidak normal & 19 & 63,3 \\
& & \\
\hline Konsistensi feses & & 73,3 \\
Keras & 22 & 26,7 \\
Lunak & 8 & \\
\hline
\end{tabular}

Dari 30 subjek, sebagian besar subjek memiliki frekuensi defekasi tidak normal, yaitu sebanyak 19 subjek $(63,3 \%)$ dengan frekuensi $<3 x$ per minggu dan mengindikasikan adanya gejala konstipasi.

Konsistensi feses subjek ditentukan menggunakan Bristol Scale. Konsistensi feses tipe 4 dan 5 merupakan tipe feses yang ideal. Pada umumnya subjek memiliki konsistensi feses kategori keras yaitu tipe feses 1-3 (73,3\%). Karakteristik feses anak autis pada periode usia 42 bulan pertama tidak berbeda dengan anak non autis. Setelah melewati periode usia 42 bulan pertama, konsistensi feses tidak lagi dipengaruhi oleh usia seperti anak non autis, melainkan faktor asupan yang idiosinkratik..$^{25}$ Jika pada anak non autis, konstipasi ditemukan pada 3\% anak usia prasekolah, dan 1-2\% pada anak usia sekolah, lain halnya dengan anak autis. Pada penelitian ini, gejala konstipasi lebih besar ditemukan pada usia sekolah $>5$ tahun.

\section{Hubungan Frekuensi Konsumsi Gluten dan Kasein dengan Pola Defekasi}

Penelitian ini menunjukkan bahwa tidak ada hubungan antara frekuensi konsumsi gluten dengan frekuensi defekasi $(r=0.150, p=0,430)$ dan konsistensi feses $(r=-0.344, p=0.062)$. Frekuensi konsumsi kasein tidak berhubungan dengan frekuensi defekasi $(\mathrm{r}=0.120, \quad \mathrm{p}=0.526) \quad$ dan konsistensi feses $(r=0.063$, $p=0.740)$.
Hal ini tidak sesuai dengan teori yang ada dimana konsumsi tinggi gluten mengakibatkan peptide tidak tercerna menjadi makanan bagi bakteri patogen dan menggangu keseimbangan mikrobakteria usus yang berperan dalam fermentasi feses. Bakteri anaerob yang berperan dalam proses fermentasi feses diantaranya spesies bifidobacterium dan eubacterium. Fermentasi ini sangat mempengaruhi konsistensi feses karena proses ini berperan dalam menurunkan $\mathrm{pH}$, meningkatkan air dalam feses dan melunakkan feses. ${ }^{10,30,31}$ Hal ini serupa dengan penelitian Mulloy bahwa konsumsi gluten dan kasein tidak berpengaruh secara keseluruhan terhadap perbaikan pencernaan, sehingga pembatasan konsumsi gluten dan kasein tidak bisa diterapkan pada semua anak autis. ${ }^{34}$

\section{Hubungan Asupan Serat dengan Pola Defekasi}

Hasil analisis korelasi Spearman menunjukkan bahwa terdapat hubungan yang antara asupan serat dengan frekuensi defekasi ( $\mathrm{r}=0.468$, $\mathrm{p}=0.009$ ) dan sangat signifikan dengan konsistensi feses $(r=0.837, p=0.000)$, yang artinya semakin tercukupi asupan serat maka frekuensi defekasi semakin normal dan konsistensi feses lunak. Penelitian Yang et al menunjukkan hal yang sama bahwa asupan serat berkorelasi positif terhadap frekuensi defekasi. ${ }^{19}$ Semakin tercukupi asupan serat maka konsistensi feses semakin lunak yaitu 
tipe feses 4 dan 5. Penelitian Hillemeier dan Ambarita menunjukkan hal yang sama bahwa asupan serat membuat konsistensi feses menjadi lunak dan bervolume sehingga memungkinkan untuk menurunkan transit time feses di dalam usus besar. $^{20,21}$

\section{SIMPULAN}

Penderita autis lebih banyak ditemukan pada laki-laki $(83,3 \%)$ dibandingkan perempuan. Sebagian besar frekuensi konsumsi gluten termasuk dalam kategori kadang $(33,3 \%)$, dan kasein dalam kategori tidak pernah $(33,3 \%)$. Rata-rata asupan serat 19,9 gram/hari dan sebagian besar asupan serat subjek kurang $(63,3 \%)$. Penelitian ini menunjukkan bahwa sebagian besar subjek $(63,3 \%)$ memiliki frekuensi defekasi yang tidak normal dan konsistensi feses yang keras $(73,3 \%)$. Hasil uji korelasi menunjukkan tidak ada hubungan antara frekuensi konsumsi gluten dan kasein dengan frekuensi defekasi dan konsistensi feses ( $p>0.05)$. Ada hubungan antara asupan serat dengan frekuensi defekasi $(\mathrm{r}=0.468, \mathrm{p}=0.009)$. Terdapat hubungan yang signifikan antara asupan serat dengan konsistensi feses $(\mathrm{r}=0.837, \mathrm{p}=0.000)$.

\section{SARAN}

Dalam pemberian diet pada anak autis, perlu dilakukan uji coba. Hal ini agar pemberian diet dapat memberikan efek yang diharapkan yaitu perbaikan . Setiap anak autis memungkinkan untuk melakukan jenis kombinasi diet yang berbeda seperti non gluten-kasein, hanya gluten/kasein saja, ataupun. Perlu dicermati juga untuk melakukan tes alergi makanan, karena adanya abnormalitas frekuensi defekasi dan konsistensi feses bisa disebabkan oleh alergi makanan.

\section{DAFTAR PUSTAKA}

1. Mitchael Mary Kay. Nutrition scross the life span. In : Nutrition for children with special needs. 2nd edition. USA : Elsevier-Saunders; 2003.p.322.

2. Centers for Disease Control and Prevention Morbidity and Mortality Weekly Report : Prevalence of Autism Spectrum Disorders-Autism and Developmental Disabilities Monitoring Network 2013. United States : Office Surveillance, Epidemology, and Laboratory Service, Center. 2013[dikutip pada tanggal 16 Januari 2014]. Diunduh dari http://www.cdc.gov/mmwr/pdf/ss/ss6103.pdf

3. Nurlaila Abdullah Mashabi, Nur Rizka Tajudin. Hubungan antara pengetahuan gizi ibu dengan pola makan anak autis. Makara Kesehatan vol 13 No.2, Desember 2009: 84-86.
4. Mark A.Gilger and Carol Anne Redel. Autism and the gut. Pediatrics 2009; 124;796-798.

5. Thea Kuddo, and Karin B, Nelson. How common are gastrointestinal disorder. Curr Opin Pediatr. 2003;15:339-343.

6. Samar H. Ibrahim, Robert G. Voigt, Slavica K. Katusic, Amy L. Weaver and William J. Barbaresi. Incidence of Gastrointestinal Symptoms in Children With Autism: A Population. Pediatrics. 2009;124;680-686.

7. Kazek, Beata, et al. Gastrointestinal disturbances in patients with autistic spectrum disorders. Pediatri Neurologia. 2001;19(38):27-31.

8. Afzal N, Murch S, Thirrupathy $\mathrm{K}$, et al. Constipation with acquired megarectum in children with autism. Pediatrics. 2003;112:939-942.

9. Daniel H, Vohwinkel M, Rehner G. Effect of casein and betacasomorphins on gastrointestinal motility. Journal of Nutrition. 1990;120:252-7.

10. S.A. Nugraheni. Sekilas tentang Belantara Autisme. Semarang: Pustaka Zaman; 2008. hal.50.

11. Tri Septiani. Efektivitas Terapi Biomedis (Modifikasi diet) terhadap Perbaikan Perilaku Autisme dan Gangguan Pencernaan Anak Autisme di SLB Putra Jaya, SD Autisme Laboratorium UM, dan Tempat Terapi A Plus Malang. Malang: Universitas Negeri Malang; 2011.

12. Sudigdo Sastroasmoro, Sofyan Ismael. Dasar-dasar Metodologi Penelitian Klinis. 2008. Jakarta : CV. Sagung Seto.

13. World Health Organization. Growth Reference. $2007 . \quad$ Diunduh dari http://www.who.int/growthref/who2007bmiforage/ en/index.html.

14. Supariasa, I Dewa Nyoman, Bachyar Bakri, Ibnu Fajar. Penilaian Status Gizi. 2001. Jakarta : EGC. hal. 97.

15. Suhardjo. Pangan, Gizi dan Pertanian. 2006. Jakarta : Universitas Indonesia. hal. 35.

16. Supariasa, I Dewa Nyoman, Bachyar Bakri, Ibnu Fajar. Penilaian Status Gizi. 2001. Jakarta : EGC. hal.114.

17. Widyakarya Pangan dan Gizi. Angka Kecukupan Gizi. 2012. Diunduh dari http://situs.opi.lipi.go.id/wnpg2012.

18. Gabrio Bassoti, Massimo Bellini, Filippo Pucciani, Renato Bocchini, Antonio Bove, Pietro Alduini, et al. An extended assesment of bowel habits in general population. World $\mathrm{J}$ Gastroenterology. 2004;10(5): 713-716.

19. Yang J, Wang Hai Peng, Zhou L, Xu Chun-Fang. Effect of dietary fiber on constipation : meta analysis. World J Gastroenterology. 2012;18(48): 7378-738.

20. Hillemeier C. An overview of the effects of dietary fiber on gastrointestina Transit. $\mathbf{J}$ American Pediatrics. 1995;96:997-999.

21. Ambarita Elyzabeth. Siti Madanijah, Nurdin Naufal. Hubungan asupan serat makanan dan air 
dengan pola defekasi anak sekolah dasar di kota Bogor. JGP. 2014;9(1): 7-14.

22. Shattock Paul, Paul Whiteley. Langkah intervensi biomedik untuk penanganan autisme dan sejenisnya (terjemahan). Seminar : Intervensi biomedis pada gangguan autisme dan sejenisnya. Yayasan Autisme Indonesia. Jakarta; 2001. 36-48.

23. Brand Susan. Nutrition Intervention for Constipation. In : Nutrition Intervention for Children with Special Health Care Needs ( breastfeeding, physical activity, and autism spectrum disorders. 3rd ed. Washington : WSDH. 2010.p.87-88.

24. Valicenti et al. Frequency of gastrointestinal symptoms in children with autistic spectrum disorder and association with family history of autoimmune disease. J Dev Behav Pediatr. 2006;27(2 suppl):S128-S136.

25. Sandhu B, Steer C, Golding J, Emond A. The early stool patterns of young children with autism spectrum disorder. Arch Dis Child. 2009;94:497500.

26. Lonnie Zwaigenbaum, Susan E, Peter Szatmari, Jessica Brian, Wendy Roberts, Isabel Smith, et al. Sex differences in children with autism spectrum disorder identified within a high-risk infant cohort. J Autism Dev Disord.

27. Rochimatun Chasanah. Gambaran Pola Konsumsi Makanan yang Mengandung Gluten dan Kasein serta Kaitannya dengan Gejala Perilaku Khas Autistik Anak Autis. [Skripsi]. Universitas Negeri Yogyakarta. 2012.

28. Yayuk Baliwati, Ali Khomsan, Meti Dwiriani. Pengantar Pangan dan Gizi. 2004. Jakarta : Penebar Swadaya. hal. 69.

29. Sugiono. Statistik Nonparametrik untuk Penelitian. 2004. Bandung : alfabeta.

30. James B Adam, Leah J Johansen, Linda D Poweel, David Quig, Robert A Rubin. Gastrointestinal flora and gastrointestinal status in children with autism comparison to typical children and correlation with autism severity. BMC Gastroenterology. 2011;11:22.

31. Peerkhan Nazni, Edward Gnanaraj, Veerappan Nishadev. Impact Casein and gluten free dietary intervention on selected autistic children. Iran J Pediatr. 2008;18(3);244-250.

32. Soenardi T. Terapi Makanan Anak dengan Gangguan Autisme. 2009. Jakarta : PT. Penerbitan Sarana Bobo

33. Dermawan, Nur Asiah. Gluten dan Alergi Susu Sapi. Majalah GiziMindo vol 6 No. 13. Desember 2005.

34. Austin Mulloy, Russel Lang, Mark O Reilly, Jeff Sigafos, Giulio Lancioni, Mandy Respoli. Glutenfree and casein-free diet in treatment of autism spectrum disorder. Elsevier.2009.10;8. 